\title{
Binding of plasma proteins to titanium dioxide nanotubes with different diameters
}

\author{
This article was published in the following Dove Press journal: \\ International Journal of Nanomedicine \\ 18 February 2015 \\ Number of times this article has been viewed
}

\author{
Mukta Kulkarni ${ }^{1}, *$ \\ Ajda Flašker ${ }^{1, *}$ \\ Maruša Lokar' \\ Katjuša Mrak-Poljšak ${ }^{2}$ \\ Anca Mazare ${ }^{3}$ \\ Andrej Artenjak ${ }^{4}$ \\ Saša Čučnik ${ }^{2}$ \\ Slavko Kralj ${ }^{5}$ \\ Aljaž Velikonja' \\ Patrik Schmuki ${ }^{3}$ \\ Veronika Kralj-Iglič \\ Snezna Sodin-Semrl|2,7 \\ Aleš Iglič' \\ 'Laboratory of Biophysics, Faculty \\ of Electrical Engineering, University \\ of Ljubljana, Ljubljana, Slovenia; \\ ${ }^{2}$ Department of Rheumatology, \\ University Medical Centre \\ Ljubljana, Ljubljana, Slovenia; \\ ${ }^{3}$ Department of Materials Science and \\ Engineering, University of Erlangen \\ Nuremberg, Erlangen, Germany; \\ ${ }^{4}$ Sandoz Biopharmaceuticals Mengeš, \\ Lek Pharmaceuticals dd, Menges, \\ Slovenia; ${ }^{5}$ Department for Materials \\ Synthesis, Institute Jožef Stefan \\ (IJS), Ljubljana, Slovenia; ${ }^{6}$ Faculty \\ of Health Studies, University of \\ Ljubljana, Ljubljana, Slovenia; ${ }^{7}$ Faculty \\ of Mathematics, Natural Science and \\ Information Technology, University \\ of Primorska, Koper, Slovenia \\ *These authors contributed equally \\ to this work
}

Correspondence: Aleš Iglič

Laboratory of Biophysics, Faculty of

Electrical Engineering, University of

Ljubljana, Tržaška 25, SI-I000 Ljubljana,

Slovenia, Slovenia

Tel +386 | 4768235

Fax +386 | 4268850

Email ales.iglic@fe.uni-lj.si

\begin{abstract}
Titanium and titanium alloys are considered to be one of the most applicable materials in medical devices because of their suitable properties, most importantly high corrosion resistance and the specific combination of strength with biocompatibility. In order to improve the biocompatibility of titanium surfaces, the current report initially focuses on specifying the topography of titanium dioxide $\left(\mathrm{TiO}_{2}\right)$ nanotubes (NTs) by electrochemical anodization. The zeta potential ( $\zeta$-potential) of NTs showed a negative value and confirmed the agreement between the measured and theoretically predicted dependence of $\zeta$-potential on salt concentration, whereby the absolute value of $\zeta$-potential diminished with increasing salt concentrations. We investigated binding of various plasma proteins with different sizes and charges using the bicinchoninic acid assay and immunofluorescence microscopy. Results showed effective and comparatively higher protein binding to NTs with $100 \mathrm{~nm}$ diameters (compared to 50 or $15 \mathrm{~nm}$ ). We also showed a dose-dependent effect of serum amyloid A protein binding to NTs. These results and theoretical calculations of total available surface area for binding of proteins indicate that the largest surface area (also considering the NT lengths) is available for $100 \mathrm{~nm}$ NTs, with decreasing surface area for 50 and $15 \mathrm{~nm}$ NTs. These current investigations will have an impact on increasing the binding ability of biomedical devices in the body leading to increased durability of biomedical devices.
\end{abstract}

Keywords: protein binding, serum amyloid A, $\beta 2$-glycoprotein I, immunoglobulin G, histone IIA

\section{Introduction}

Hemocompatible nanomaterials can be used as scaffolds for various clinical devices, such as biosensors, dental devices, ${ }^{1,2}$ craniofacial implants $^{3,4}$ and cardiovascular stents. 5,6 In all these cases, hemocompatibility and antimicrobial/anti-inflammatory properties of these devices are prime considerations. Biocompatible devices can be made out of different materials, such as metals (stainless steel, tantalum, cobalt alloys, titanium and its alloys), ceramics (aluminum oxide, zirconia, and calcium phosphates), and synthetic or natural polymers. ${ }^{7}$ Titanium (Ti) and its alloys are considered as one of the most significant biocompatible material for medical applications due to resistance to body fluid effects, great tensile strength, flexibility, and high corrosion resistance. ${ }^{8}$ Structures present in the human body are not only in micrometer but also in nanometer scale, such as the bone, which is made up of nanostructures. To produce better biocompatible materials, the surfaces of these materials must be nanostructured. ${ }^{9}$ An easy method to obtain nanostructures and to control the obtained nanotopography is electrochemical anodization; other methods include hydrothermal treatments or sol-gel methods. ${ }^{10}$ Generally, nanoscale surfaces increase roughness and possess high effective surface area, which may lead to increasing initial protein adsorption that is a very important first step in regulating cellular interactions of the implant. Surface physical and chemical 
properties of the material have an impact also on adhesion, together with charge distribution. ${ }^{11-13}$

As $\mathrm{TiO}_{2}$ surfaces and cell membranes are both negatively charged, there is a need for a mediator that shields the repulsive force between the negatively charged biosurfaces. ${ }^{9}, 14$ These can be proteins or divalent ions which bridge the repulsive electrostatic interactions between equally charged surfaces. ${ }^{9}$ However, other interactions, such as strong chemisorption energies, ${ }^{15,16}$ and hydrophobic interactions ${ }^{17}$ also need to be taken into consideration when trying to explain protein interactions with $\mathrm{TiO}_{2}$ surfaces. The interactions of proteins with biomaterial are of great importance because of their presence in plasma and potential functions in wound healing and inflammatory responses.

Previous reports have shown binding of different protein or peptide interlayers, such as growth factors, ${ }^{18}$ albumin, fibrinogen, IgG, ${ }^{13,19}$ fibronectin, ${ }^{20}$ collagen type $1,{ }^{21}$ BMP- $2,{ }^{18,22}$ RGD peptide, ${ }^{23}$ and laminin-derived peptide, ${ }^{24}$ to $\mathrm{TiO}_{2}$ nanotubes (NTs), which could provide for crucial information concerning their integration into the body. The majority of the more recent investigations studied the combination of different cell types with different prebound proteins ${ }^{25,26}$ on $\mathrm{TiO}_{2}$ NTs and found that binding is cell-specific and cannot be generalized. However, reports on hemocompatibility with $\mathrm{TiO}_{2}$ nanostructured material are rare, with exceptions, such as plasma protein adsorption binding studies by Smith et $\mathrm{al}^{13,27}$ and binding of collagen type 1 by Yang et $\mathrm{al}^{21}$ with an explanation of interaction energies and main driving forces.

Proteins studied in the current report were serum amyloid A (SAA), $\beta 2$-glycoprotein I ( $\beta 2 \mathrm{GPI}), \beta 2 \mathrm{GPI}$-derived peptides, immunoglobulin $\mathrm{G}$ ( $\operatorname{IgG}$ ), oxygenized $\operatorname{IgG}$ (oxIgG), and a non-plasma protein, histone IIA. In addition to plasma proteins, we also examined histone IIA, a small nuclear DNA binding protein, because of its small molecular weight of $14 \mathrm{kDa}$ and positive charge, due to rich lysine residues..$^{28,29}$ It served as a non-plasma protein control.

SAA is a major acute phase protein which is rapidly upregulated during inflammatory events such as infections, wounds, and injuries. ${ }^{30,31}$ The role of the acute phase response is prevention of pathogen entry, neutralization and clearing of pathogens, minimization of tissue damage that leads to wound healing, and restoring of homeostasis..$^{30,32} \mathrm{SAA}$ is a relatively small protein of $\sim 12 \mathrm{kDa}^{33}$ with $\sim 80 \%$ alpha helical conformation. ${ }^{34}$

ß2GPI, also known as apolipoprotein $\mathrm{H},{ }^{35}$ is a multifunctional $53 \mathrm{kDa}$ glycosylated plasma protein ${ }^{36}$ with physiological values of $20-300 \mathrm{mg} / \mathrm{L} .{ }^{37}$ The protein consists of 326 amino acids folded into five domains, where the fifth domain is positively charged, with a lysine-rich region ${ }^{281}$ CKNKEKKC, ${ }^{288}$ a hydrophobic loop ${ }^{313} \mathrm{LAFW},{ }^{316}$ and extended C-terminal domain, that enable binding to negatively charged phospholipids. ${ }^{38-40}$ After binding to phospholipids, $\beta 2 \mathrm{GPI}$ changes its conformation from circular to open fish-hook, exposing a cryptic epitope which is recognized by antibodies against $\beta 2$ GPI (anti- $\beta 2$ GPI) directed against domain I. ${ }^{41}$ Zager et al also reported that anti- $\beta 2$ GPI recognize both native and conformational epitopes located on different domains of anti$\beta 2 \mathrm{GPI} .{ }^{42}$ Anti- $\beta 2 \mathrm{GPI}$ represents one of the main subgroups of antiphospholipid antibodies and is one of the laboratory criteria for classification of antiphospholipid syndrome. ${ }^{43}$

IgG antibodies are large molecules of about $150 \mathrm{kDa}$ and are the predominant antibody isotype in normal human serum. IgG accounts for $70 \%-75 \%$ of the total serum antibody pool and consists of a monomeric four-chain molecule. The normal concentration range is $6.0-16 \mathrm{~g} / \mathrm{L} .{ }^{44}$ Oxidation of normally protective polyclonal IgG antibodies isolated from healthy blood donors by various agents resulted in severe alteration of their specificity and increased affinity to selfantigens. ${ }^{45-47} \beta 2 \mathrm{GPI}$, one of the main pathologically relevant antigens in antiphospholipid syndrome, was reported to be recognized by oxidatively altered $\operatorname{IgG} / \operatorname{IgM} .^{47,48}$

Peptide binding to $\mathrm{TiO}_{2}$ NTs has been used predominantly for studying the increase of cell adhesion and osteogenic gene expression ${ }^{22,23,49}$ as well as for soft tissue interactions ${ }^{24}$ and local delivery of antimicrobial peptides..$^{50} \mathrm{~A}$ hexapeptide motif was found to bind electrostatically to titanium surfaces, with potential important osteogenic consequences. ${ }^{17}$

Therefore, we tested the binding of plasma proteins with different molecular weights, charges, and functions to $\mathrm{TiO}_{2} \mathrm{NTs}$ with specific diameters. Nanotubular surfaces were designed by specific electrochemical anodization of the metallic substrate. ${ }^{10,14,51-55}$ Prepared $\mathrm{TiO}_{2}$ nanotubular structures have nanorough surfaces with sharp edges and spikes which promote the binding of proteins and thus better/ stronger adhesion of certain cell types., ${ }^{9} 14,56$

Our aim was to investigate whether plasma proteins, not previously reported, can bind to $\mathrm{TiO}_{2}$ NTs and characterize if the binding is dependent on nanotube diameter, protein molecular size, charge, or conformation and determine whether the interaction is dose-dependent.

\section{Materials and methods Growth of titanium dioxide NTs by electrochemical anodization}

To obtain different $\mathrm{TiO}_{2}$ NTs, $0.1 \mathrm{~mm}$ thick titanium foils (Advent Research Materials Ltd., UK) of $99.6 \%$ purity 
were used. Prior to anodization, titanium foils were cleaned by successive ultrasonication in acetone, ethanol, and deionized water for 5 minutes and dried in nitrogen stream. Actually, the anodization method is a two-step process. In the first step, NTs are grown in ethylene glycol (EG) plus 0.1 $\mathrm{M} \mathrm{NH}_{4} \mathrm{~F}$ plus $1 \mathrm{M} \mathrm{H}_{2} \mathrm{O}$ at $35 \mathrm{~V}$ for 2 hours. The NTs were removed by ultrasonication in water and the obtained pretreated sample (after cleaning again by ultrasonication - as initially performed, and dried in nitrogen stream) was subsequently used as substrate for obtaining the final nanostructures with the desired diameters. EG-based electrolytes, with hydrofluoric acid as the source of $\mathrm{F}^{-}$ions with specific amount of water, were used in the second anodization step, under various applied potentials for obtaining the desired different diameter NTs. Specifically, the electrolyte was EG plus $8 \mathrm{M}$ water plus $0.2 \mathrm{M}$ hydrofluoric acid and the anodization time of 2.5 hours was used for obtaining all nanostructures $(15,50$, and $100 \mathrm{~nm})$, while the applied potential was $58 \mathrm{~V}$ for $100 \mathrm{~nm}, 20 \mathrm{~V}$ for $50 \mathrm{~nm}$, and $10 \mathrm{~V}$ for $15 \mathrm{~nm}$. The NTs thus formed were kept in ethanol for 2 hours to remove all organic components from the electrolyte, washed with distilled water, and dried under nitrogen stream. ${ }^{57}$ Anodization parameters were optimized in order to get the specific morphology NTs. ${ }^{10}$ All the anodization experiments were carried out at room temperature $\left(\sim 20^{\circ} \mathrm{C}\right)$ in a two-electrode system with titanium foil as the anode and platinum gauze as the cathode. Freshly made and non-autoclaved NTs were used in further experiments.

\section{Electron microscopy}

The morphology of the formed $\mathrm{TiO}_{2}$ NTs was evaluated using a field-emission scanning electron microscope (SEM) (Hitachi S4800), which was used to acquire the top view of the NTs, as previously described. ${ }^{58}$ Transmission electron microscopy (TEM) (JEM 2100; JEOL, Tokyo, Japan) characterization of the NT samples was performed as follows. The NTs were collected from the titanium foil support by mechanical scratching and dispersed in distilled water. Drops of distilled water with the dispersed NTs were placed on a copper-grid-supported perforated transparent carbon foil. The high-resolution TEM images were taken at the edges of the NT clusters jutted into a hole in the carbon foil. Top and cross-section views were obtained from mechanically cracked samples. The mean standard values for diameters, spacing, and length of the nanotubular structures and the standard deviation values were determined by analyzing images from three different samples for each nanostructure.

\section{Zeta potential of $\mathrm{TiO}_{2} \mathrm{NTs}$}

The suspension of sheared $\mathrm{TiO}_{2}$ NTs was monitored with electrokinetic measurements of the zeta potential ( $\zeta$-potential) (Brookhaven Instruments Corporation, ZetaPALS). For determination of the $\zeta$-potential, their aqueous suspension was used as a function of the $\mathrm{pH}$. Prior to the experiment, the $\mathrm{pH}$ of the aqueous suspension was set to the desired value with the $\mathrm{HCl}$ or $\mathrm{NaOH}(0.01 \mathrm{M})$ solutions.

\section{Theoretical approach for determining the $\zeta$-potential}

$\zeta$-potential can be also determined using various theoretical approaches. In this study, the Stern-Gouy-Chapman model and Gongadze-Iglič (GI) model were combined to calculate electric potential near a negatively charged planar surface with negative surface charge density. ${ }^{59,60}$ In the Stern layer, the Gouy-Chapman equation was applied, while in the diffuse layer, the GI equation was used. As $\zeta$-potential was experimentally measured at the distance greater than the distance of closest approach (b) - the distance of the plane dividing the Stern and diffuse layers - the electric potential was also calculated only in the diffuse layer.

\section{Biological material}

Proteins used in the NT binding experiments were either purchased as lyophilized material and reconstituted according to manufacturer's instructions or isolated from human biological material, as described below. $\beta 2$ GPI was isolated from human plasma using a combination of perchloric acid precipitation and heparin affinity/cationic exchange chromatography. ${ }^{61}$ Human polyclonal IgG were isolated from sera of healthy blood donors by affinity chromatography HiTrap ${ }^{\mathrm{TM}}$ Protein G HP column (GE HealthCare Bio-Sciences AB, Uppsala, Sweden) as previously described. Oxidatively altered IgG (oxIgG) with increased immunoreactivity to $\beta 2 \mathrm{GPI}$ and its peptide clusters influence human coronary artery endothelial cells. ${ }^{62}$ Isolated $\mathrm{IgG}$ were oxidized as previously reported ${ }^{48}$ with exposure to direct current using graphite stick electrodes on a current/voltage generator. Isolated IgGs were denatured by boiling the protein samples at $95^{\circ} \mathrm{C}$ for 5 minutes (in 2720 Thermal Cycler; Thermo Fisher Scientific, Waltham, MA, USA) in denaturation buffer ( $2 \%$ sodium dodecyl sulfate [SDS]; Bio-Rad Laboratories Inc., Hercules, CA, USA), $0.01 \%$ (w/v) $\beta$-mercaptoethanol (Riedel-de Haën, Hannover, Germany), $1 \mathrm{mM}$ dithiothreitol (Sigma-Aldrich Co., St Louis, MO, USA) in phosphate buffered saline (PBS), $\mathrm{pH}$ 7.4. Lyophilized histone from calf thymus type II-A (Sigma ${ }^{\circledR}$, Sigma-Aldrich Co.) and lyophilized human recombinant 
SAA (Peprotech, Rocky Hill, NJ, USA) were resuspended and/or diluted with PBS and sterilized with filter $(0.20 \mu \mathrm{m}$ pores; Acrodisc ${ }^{\circledR}$; Pall Corporation, Ann Arbor, MI, USA).

The sequences of peptide 1 (QGPAHSK) and peptide 2 (KMDGNHP) were found using heptapeptide phage display library by Zager et al. ${ }^{42}$ The amino acid sequence QGPAHSK represents a mimotope of the conformational epitope that resides on the third domain of $\beta 2 \mathrm{GPI}$ and is recognized by more than $30 \%$ share of high-avidity anti- $\beta 2$ GPI antibodies. The amino acid sequence KMDGNHP represents a mimotope of the conformational epitope between the third and fourth domain of $\beta 2$ GPI that is recognized by more than $30 \%$ share of polyclonal low avidity anti- $\beta 2 \mathrm{GPI}$ antibodies when $\beta 2 \mathrm{GPI}$ is in open conformation. Peptide 1 and peptide 2 used in the current experiments had an additional tail added at the N-terminus GGGS $\mathrm{NH}_{2}$.

\section{Binding of different proteins to $\mathrm{TiO}_{2}$ NTs and protein quantification}

For assessment of total bound proteins on NTs, a microassay procedure from the Thermo Scientific ${ }^{\mathrm{TM}}$ Pierce $^{\mathrm{TM}}$ BCA protein assay (Thermo Fisher Scientific) was used. Bovine serum albumin (BSA) served as a standard, as supplied in the BCA protein assay. According to the microassay procedure, the standard curve range was $20-2,000 \mu \mathrm{g} / \mathrm{mL}$.

For the $\mathrm{TiO}_{2} \mathrm{NT}$ binding experiments (as represented by Figure 1), $5 \times 5 \mathrm{~mm}$ square $\mathrm{TiO}_{2}$ NTs of different diameter specifically 100,50 , and $15 \mathrm{~nm}$ - were used. As a control

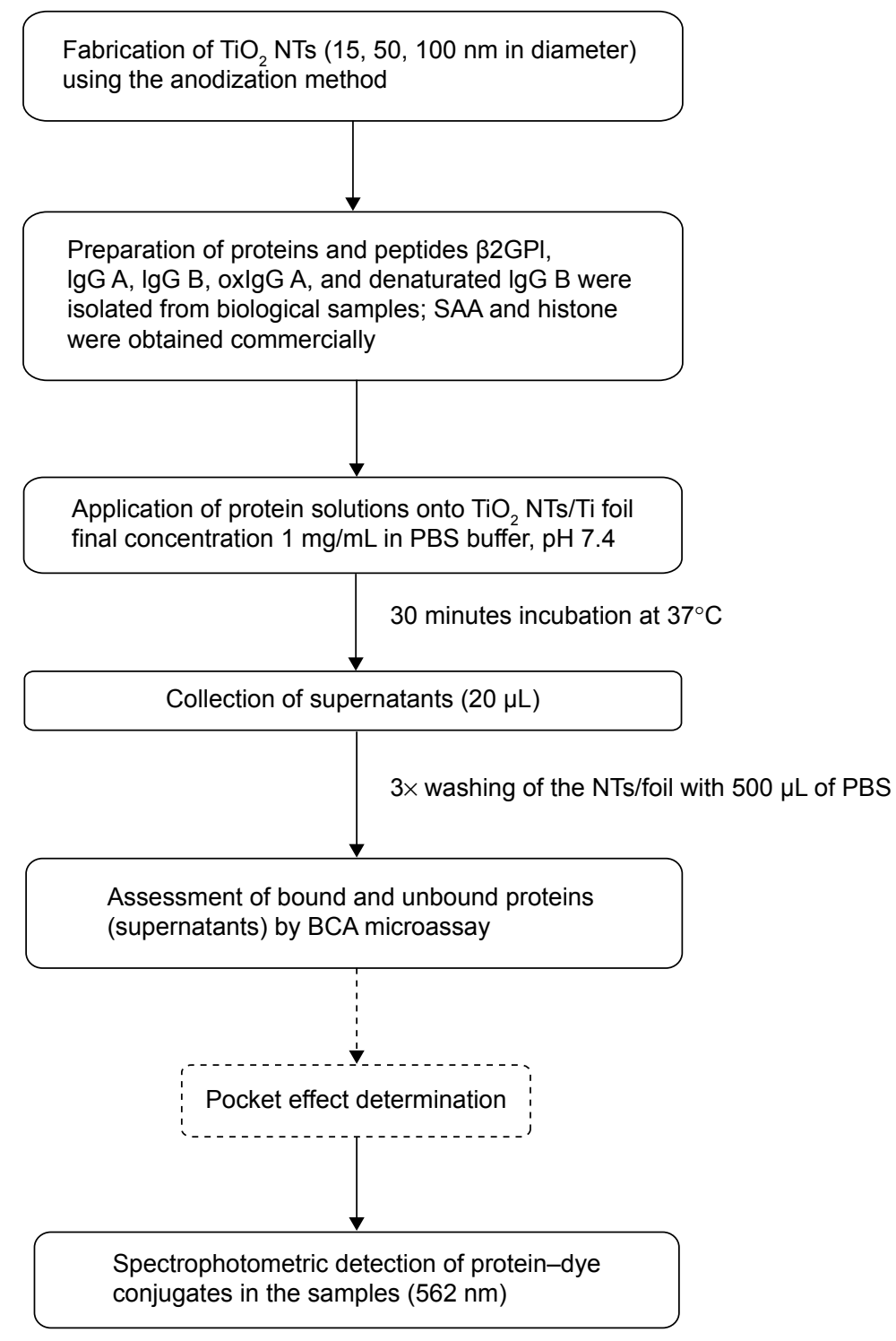

Figure I Protocol for quantification of protein binding to $\mathrm{TiO}_{2} \mathrm{NTs} / \mathrm{Ti}$ foil.

Abbreviations: oxlgG, oxygenized lgG; NTs, nanotubes; PBS, phosphate buffered saline; SAA, serum amyloid A. 
for nonspecific binding, titanium foil (the template on which NTs are "grown") was used.

Protein quantification was performed as described below. As the first step, $20-40 \mu \mathrm{L}$ of protein samples $(25 \mu \mathrm{g}$ of protein if not stated otherwise) in the form of a droplet was carefully pipetted onto the surface of $\mathrm{TiO}_{2} \mathrm{NTs} / \mathrm{Ti}$ foil that were placed in 24-well plates (TPP Techno Plastic Products AG, Trasadingen, Switzerland) and incubated for 30 minutes at $37^{\circ} \mathrm{C}$. As a negative control, PBS was used. After incubation, $20 \mu \mathrm{L}$ samples of supernatants were collected and the NTs/foils were washed three times repeatedly with $500 \mu \mathrm{L}$ of PBS and transferred into fresh wells. Twenty microliters of PBS and $200 \mu \mathrm{L}$ of BCA working reagent (prepared according to the manufacturer's instructions, by mixing 50 units of reagent $A$ with 1 unit of reagent $B$ ) were applied into each 24-well plate with the NTs or foil. At the same time, $20 \mu \mathrm{L}$ of BSA standards or starting protein samples (in concentrations applied on NTs/foil) with $200 \mu \mathrm{L}$ of BCA working reagent were pipetted into 96-well plates (MaxiSorp, MicroWell, Nunc-Immuno, Thermo Fisher Scientific). After incubation for 30 minutes at $37^{\circ} \mathrm{C}$, the same volume of all samples from NTs/foil in 24-well plates was transferred to 96-well plates (with BSA standards and protein starting material) and absorbance was measured at a wavelength of $562 \mathrm{~nm}$ with a Sunrise Tecan spectrophotometer (Tecan Trading AC, Maennedorf, Switzerland) (Figure 1). According to the instructions of Thermo Scientific ${ }^{\mathrm{TM}}$ Pierce $^{\mathrm{TM}} \mathrm{BCA}$ protein assay, the correction factors for determination of exact protein concentrations (masses) were used. Where correction factors were not known, we estimated experimental correction factors calculated from the determined concentrations in BCA protein assay based on BSA standard curve and based on the known starting concentrations of the studied proteins. The results were analyzed with two-way analysis of variance and Bonferroni posttests.

\section{"Pocket effect" monitoring}

After initial protein determination with BCA, NTs/foil were washed three more times with $500 \mu \mathrm{L}$ of PBS and three times with $500 \mu \mathrm{L}$ of $\mathrm{dH}_{2} \mathrm{O}$ (first washing). Bound protein concentration was again measured with BCA as described in "Biological material", using the same BSA standard dilutions. Afterwards, the NTs/foil were washed again, first briefly with $1,000 \mu \mathrm{L}$ of PBS and twice by flushing rigorously four to six times. This washing step was repeated with $\mathrm{dH}_{2} \mathrm{O}$ (second washing). Protein concentration was measured for the third time as described before with the same BSA standards.

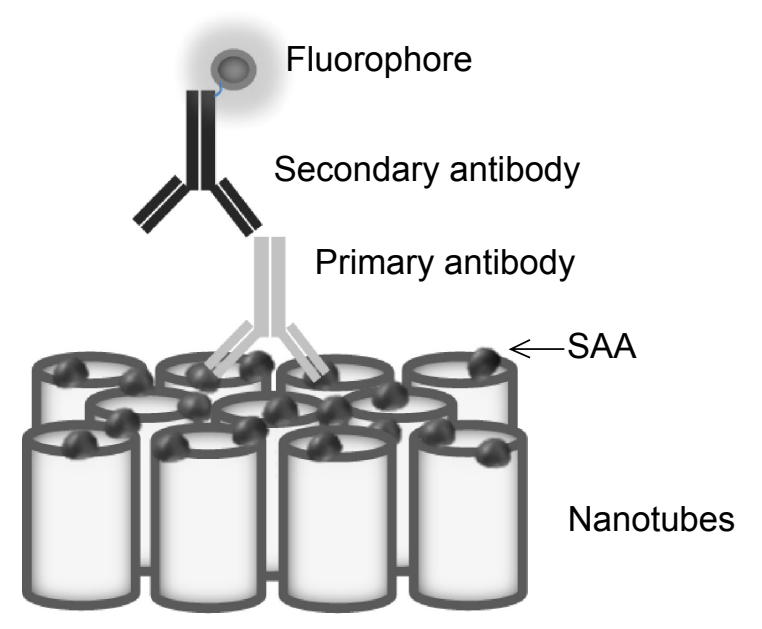

Figure 2 Schematic representation of immunofluorescent detection of SAA protein binding to $\mathrm{TiO}_{2}$ nanotubes.

Abbreviation: SAA, serum amyloid $A$.

\section{Immunofluorescent microscopy and intensity determination}

For immunochemistry determination, different doses of SAA $(20,2$, and $0.2 \mu \mathrm{g})$ were used on NTs with different diameter pore sizes $(100,50$, and $15 \mathrm{~nm})$ and on foil. After binding of SAA, NTs and foil were washed three times with PBS buffer and incubated in blocking buffer (1\% BSA and $5 \%$ milk) for 30 minutes. NTs and foil were washed again three times with PBS and incubated with primary antibody against human SAA (Reu86.1; Santa Cruz Biotechnology Inc., Dallas, TX, USA). After 1 hour of incubation, the samples were washed three times with PBS and incubated with secondary goat anti-mouse antibody labeled with FITC (Santa Cruz Biotechnology Inc.) for 30 minutes (Figure 2). After washing with PBS, the samples were observed using a fluorescent microscope (Nikon eclipse E400) and images were taken with a digital camera (Nikon Instruments, Melville, NY, USA) and Nikon ACT-1 imaging software. Four different measurements of fluorescence intensity were made for each sample with ImageJ software. An average of four replicates were normalized with an average of background fluorescence $(0 \mu \mathrm{g} \mathrm{SAA})$. The intensity of fluorescent signal of different doses of SAA on different pore size of NTs and foils was compared. The results were analyzed with two-way analysis of variance and Bonferroni posttests.

\section{Results \\ Morphology of titanium dioxide NTs as determined by SEM and TEM}

By tailoring the anodization conditions (applied voltage, anodization time, and electrolyte composition), vertically oriented 
NTs with different diameters were obtained. The use of the double anodization method leads to a clean top surface, ie, no initiation layer or nanograss formation. ${ }^{10}$ The average diameters of the obtained nanotubular structures were $15 \mathrm{~nm}, 50 \mathrm{~nm}$, and $100 \mathrm{~nm}$, while the standard deviations for each type of diameters were $\pm 13 \%, \pm 10 \%$, and $\pm 5 \%$, respectively. The length of the NTs was determined from cross-section images for each diameter of NTs (images not shown); that is, for $15 \mathrm{~nm}$, $50 \mathrm{~nm}$, and $100 \mathrm{~nm}$ diameters, the length was $370 \mathrm{~nm}, 1 \mu \mathrm{m}$, and $3.7 \mu \mathrm{m}$ with standard deviations of $\pm 8 \%, \pm 5 \%$, and $\pm 2.7 \%$, respectively. Top-view SEM images of the obtained nanotubular surfaces, indicating well-controlled diameters and an open top of the NTs, are shown in Figure 3.

TEM images (shown in Figure 4) confirmed the diameters and alignments of NT clusters. Furthermore, the TEM images put into evidence the inner shape of the nanotubular structure, which is a 'V-shape' meaning that the inner diameter decreases along the length from top to bottom, while the tube wall thickness increases. ${ }^{10}$ For example, comparing TEM images in Figure 4B (15 nm) with Figure 4F and G (50 nm), and with Figure $4 \mathrm{~J}$ and K (100 nm), a difference in both the tube wall thickness and inner diameter between top and bottom of each nanostructure is observed. It follows that, due to the higher values, it is easier to observe the "V-shape" for larger-diameter NTs (100 nm) than for smaller-diameter NTs (50 or $15 \mathrm{~nm}$ diameter); nevertheless, this "V-shape" is present in all obtained nanostructures.

\section{$\zeta$-potential of $\mathrm{TiO}_{2} \mathrm{NTs}$}

The changes in the NTs' surface charge were followed by measurements of the $\zeta$-potential of their aqueous suspension as a function of the applied $\mathrm{pH}$ (Figure 5). The $\mathrm{TiO}_{2} \mathrm{NTs}$ show a relatively acidic character for the whole range of considered $\mathrm{pH}$ values. The NTs have an isoelectric point (IEP) at a $\mathrm{pH}$ of 4.9. The $\zeta$-potential curve reached negative values lower than $-25 \mathrm{mV}$ at $\mathrm{pH}$ values above 6.5. The high absolute values of the NTs' $\zeta$-potential in neutral and basic conditions provide strong electrostatic repulsive forces with the negatively charged colloids and strong attraction forces with the positively charged colloids. We measured $\zeta$-potential for all three diameters of NTs $(15,50$, and $100 \mathrm{~nm})$. The $\zeta$-potential values of all three diameters of NTs were not significantly different and the $\zeta$-potential curves of the $\mathrm{TiO}_{2} \mathrm{NTs}$ (with 15,50 , and $100 \mathrm{~nm}$ diameter) as a function of $\mathrm{pH}$ in water are shown in Figure 5.

ל-potential measurements of NTs' surfaces were also measured at different concentrations of salt in PBS buffer solution (Table 1). For comparison, the $\zeta$-potential dependence on salt concentration in PBS was also predicted theoretically (Figure 6) using the combination of Stern and GI models. ${ }^{59,60,63}$ As expected, we observed the decrease in negative $\zeta$-potential values (ie, increase in the absolute value of $\zeta$-potential) with increase in dilution of PBS solution (ie, with a decrease in salt concentrations) in experiments and theory. The agreement between the measured (Table 1) and theoretically predicted
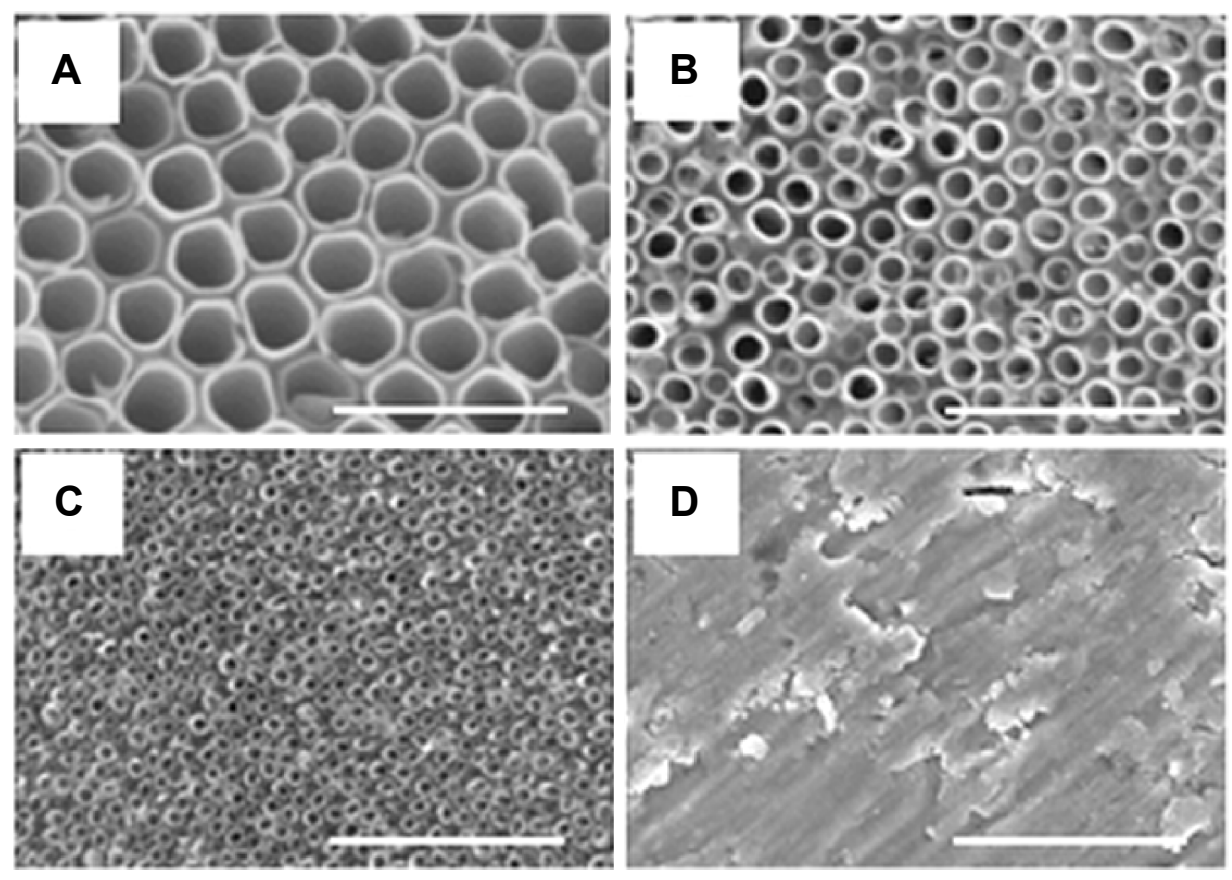

Figure 3 Scanning electron microscope images of the top surface of $\mathrm{TiO}_{2}$ nanotubes of different diameters.

Notes: (A) $100 \mathrm{~nm}$, (B) $50 \mathrm{~nm}$, (C) $15 \mathrm{~nm}$, and (D) titanium foil. Scale bar is $500 \mathrm{~nm}$. 

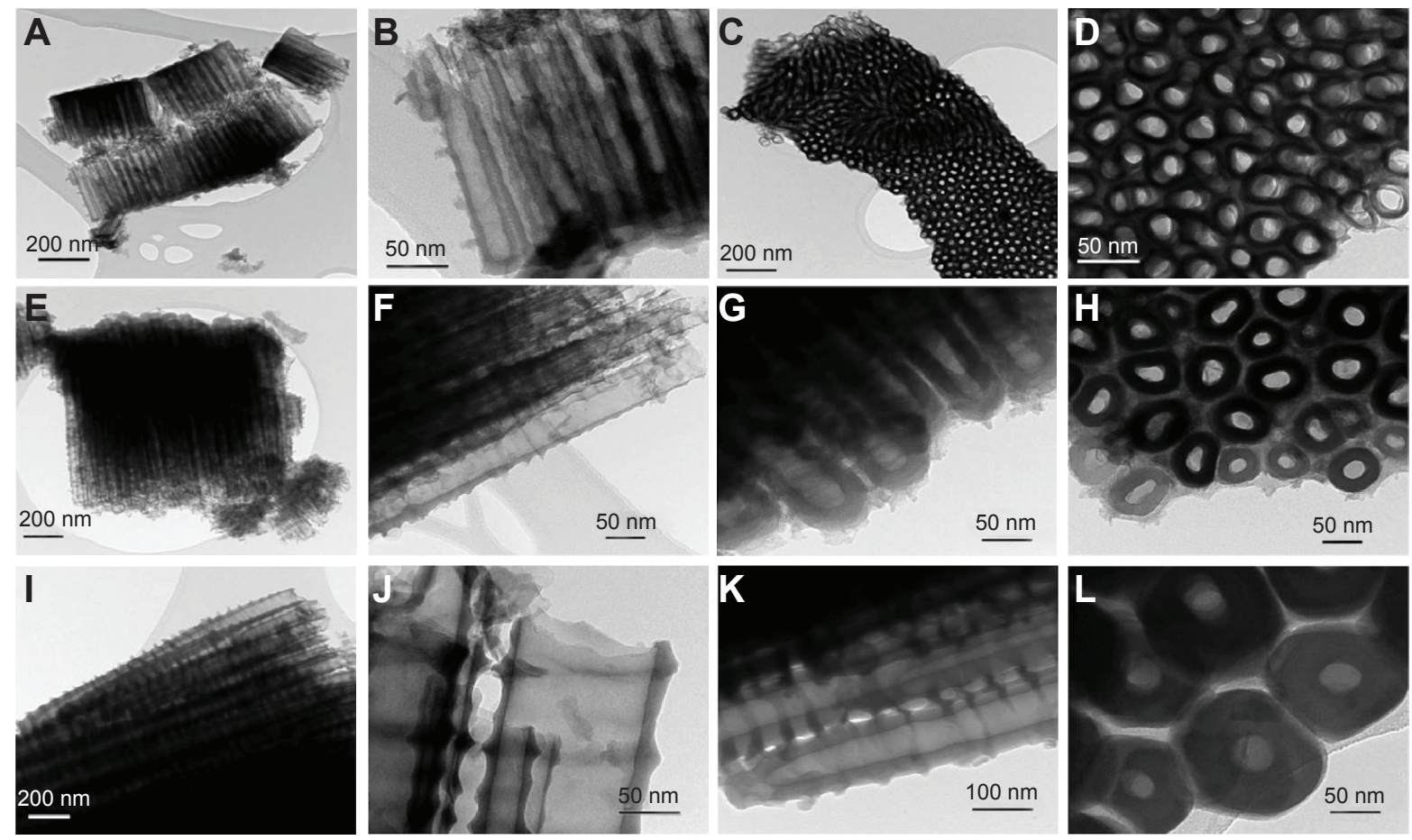

Figure 4 Transmission electron microscopy images of the $\mathrm{TiO}_{2} \mathrm{NTs}$.

Notes: (A-D) Represents the NTs with $15 \mathrm{~nm}$ diameters; (E-H) represents the NTs with $50 \mathrm{~nm}$ diameters; and (I-L) represents the NTs with $100 \mathrm{~nm}$ diameters. Abbreviation: NTs, nanotubes.

(Figure 6) dependence of $\zeta$-potential on salt concentration is better for larger salt concentrations.

\section{Experimental binding of different proteins and peptides to NTs}

Binding of SAA, $\beta 2 \mathrm{GPI}$, IgG (from two different donors, namely IgG A and IgG B), oxIgG A, and histone IIA proteins which possess different characteristics was studied on 100,50 , and $15 \mathrm{~nm}$ NT surfaces and titanium foil. We observed that proteins of different sizes and characteristics (11-150 kDa; different charges and IEP) can all bind to NTs of different diameters; however, the binding of all those

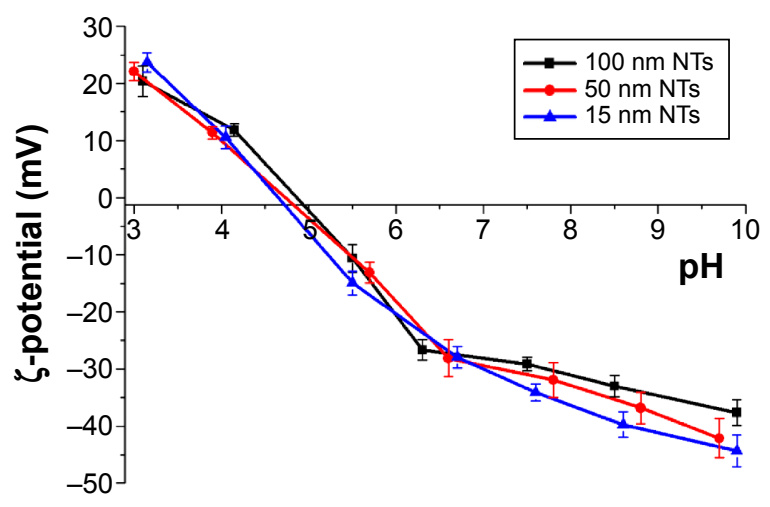

Figure 5 -potential curves of the $\mathrm{TiO}_{2} \mathrm{NTs}$ (with $15 \mathrm{~nm}, 50 \mathrm{~nm}$, and $100 \mathrm{~nm}$ diameters) as a function of $\mathrm{pH}$ in water.

Abbreviation: NTs, nanotubes. proteins significantly decreases with decreasing diameter of the NTs. The highest binding for all proteins observed was for $100 \mathrm{~nm}$ NT a and the binding decreased with smaller NTs' pore diameter $(100 \mathrm{~nm} \mathrm{NT}>50 \mathrm{~nm} \mathrm{NT}>15 \mathrm{~nm} \mathrm{NT}>\mathrm{Ti}$ foil) (Table 2; Figure 7). We examined the highest relative fold changes of bound mass on $100 \mathrm{~nm}$ NTs, compared to Ti foil. The highest change was observed with histone IIA, where the bound mass was 8.2-times higher for $100 \mathrm{~nm}$ NTs as compared to foil, followed by plasma proteins SAA (7.2×), oxIgG A (5.0×), IgG A (4.8×), and $\beta 2$ GPI (4.5×). With lowering of NT diameter, bound protein mass almost linearly decreased. Interestingly, with $50 \mathrm{~nm} \mathrm{NTs}$, the amount of bound proteins was decreased by half (49\%-62\%) (for all proteins), while on $15 \mathrm{~nm} \mathrm{NTs}$, around one-third (29\%-41\%) of proteins were bound in comparison to $100 \mathrm{~nm} \mathrm{NTs}$.

Table I Zeta potential values of NT $100 \mathrm{~nm}$ in various concentrations of salts in PBS

\begin{tabular}{ll}
\hline Dilutions of PBS & $\zeta$-potential $(\mathbf{m V})$ \\
\hline I-I PBS & $-25.7 \pm 3.0$ \\
I-I.3 PBS & $-27.6 \pm 3.7$ \\
I-I.5 PBS & $-36.5 \pm 3.5$ \\
I-2 PBS & $-39.8 \pm 3.3$ \\
I-I0 PBS & $-48.6 \pm 1.9$ \\
I-100 PBS & $-55.1 \pm 1.3$ \\
\hline
\end{tabular}

Notes: The numbers in the sample represent dilutions (PBS - distilled water). Zeta potential values are shown as mean \pm standard deviation.

Abbreviations: PBS, phosphate buffered saline; NT, nanotube. 


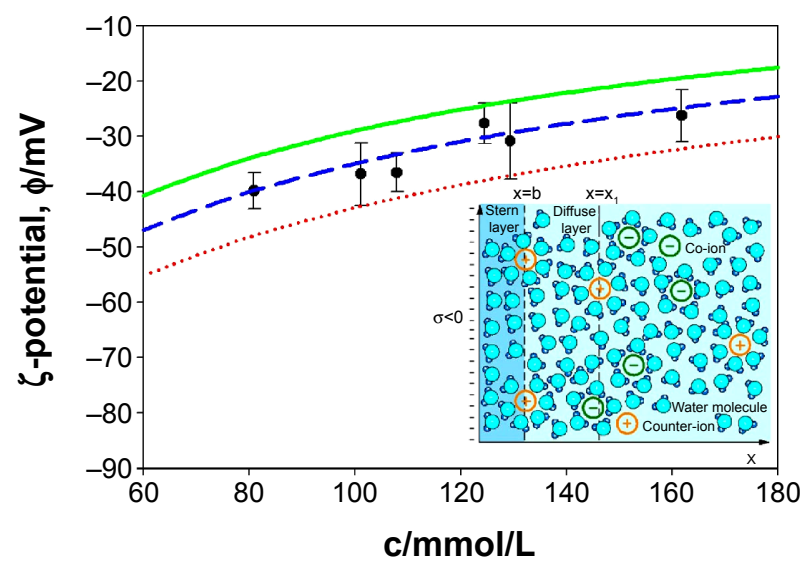

Figure $6 \zeta$-potential of NTs obtained from experiments (points) and theoretical (curves) consideration in dependence of monovalent salt concentration in PBS buffer solution.

Notes: The theoretical values of $\zeta$-potential were calculated at three different values of the distance from the charged plane $\left(x_{1}\right): 1.0 \mathrm{~nm}$ (red dotted line), $1.2 \mathrm{~nm}$ (blue dashed line), and $1.4 \mathrm{~nm}$ (green full line). Other model parameters are: water dipole moment $P_{0}=3.1 \mathrm{D}$, bulk concentration of water $\mathrm{n}_{\mathrm{ow}} / \mathrm{N}_{\mathrm{A}}=55 \mathrm{~mol} / \mathrm{L}$, temperature $=298 \mathrm{~K}$, surface charge density $\sigma=-0.1 \mathrm{As} / \mathrm{m}^{2}$, and distance of closest approach $=0.4 \mathrm{~nm} .{ }^{60,63}$ Inset: graphical presentation of Stern and diffuse electric double layer. Outer Helmholtz plane is located at $\mathrm{x}=\mathrm{b}$ (distance of closest approach) which is approximately equal to the hydrated radius of the counter-ions. $\zeta$-potential plane is calculated at the distance $x=x$ from the negatively charged surface located at $\mathrm{x}=0$.

Abbreviations: c, salt concentration; PBS, phosphate buffered saline.

On Ti foil, only a small amount (12\%-24\%) of proteins was bound; the binding did not exceed $25 \%$, which clearly indicates that the titanium foil is less eligible for protein binding. Surprisingly, all the examined proteins showed the same trends and ratios of binding on different NTs (Figure 7). Even histones IIA did not seem to be an exception, although they are small, basic proteins not found in plasma.

In order to determine whether different domains of $\beta 2 \mathrm{GPI}$ antigen were important for binding to NTs, we used two different peptides representing surface amino acid clusters on $\beta 2 \mathrm{GPI}$. Interestingly, the peptides significantly differ from

Table 2 Binding of different proteins/peptides to 100, 50, and $15 \mathrm{~nm}$ NTs

\begin{tabular}{|c|c|c|c|c|c|}
\hline \multirow[t]{2}{*}{ Protein } & \multicolumn{5}{|c|}{ Mass of bound proteins/peptides } \\
\hline & $\begin{array}{l}\text { Initial mass } \\
\text { of the protein } \\
\text { on NTs }(\mu \mathrm{g})\end{array}$ & $\begin{array}{l}100 \mathrm{~nm} \\
\text { NTs } \\
(\mu \mathrm{g})\end{array}$ & $\begin{array}{l}50 \mathrm{~nm} \\
\text { NTs } \\
(\mu \mathrm{g})\end{array}$ & $\begin{array}{l}15 \mathrm{~nm} \\
\text { NTs } \\
(\mu \mathrm{g})\end{array}$ & $\begin{array}{l}\text { Foil } \\
(\mu \mathrm{g})\end{array}$ \\
\hline$\beta 2 \mathrm{GPI}$ & 20.73 & 3.92 & 2.05 & 1.38 & 0.88 \\
\hline SAA & 22.19 & 5.26 & 2.60 & 2.16 & 0.73 \\
\hline $\lg G \mathrm{~A}$ & 25.29 & 3.38 & 2.09 & 1.40 & 0.71 \\
\hline oxlgG $A$ & 24.83 & 3.83 & 2.07 & 1.45 & 0.76 \\
\hline Histone IIA & 14.50 & 4.65 & 2.79 & 1.83 & 0.57 \\
\hline Peptide I of $\beta 2$ GPI & 24.85 & 2.26 & 2.08 & 2.32 & 1.84 \\
\hline Peptide 2 of $\beta 2 \mathrm{GPI}$ & 25.82 & 8.52 & 6.14 & 5.90 & 5.99 \\
\hline
\end{tabular}

Abbreviations: $\beta 2 \mathrm{GPI}, \beta 2$-glycoprotein I; NT, nanotube; oxlgG A, oxidized $\lg \mathrm{A}$; SAA, serum amyloid $A$.

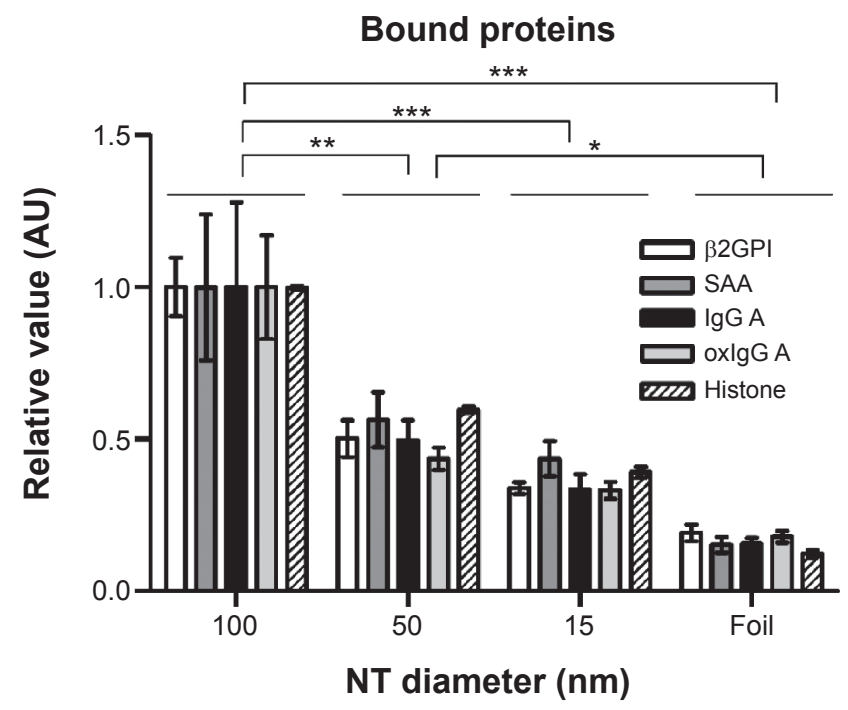

Figure 7 Relative value (normalized to $100 \mathrm{~nm} \mathrm{NT)} \mathrm{of} \mathrm{bound} \mathrm{protein} \mathrm{mass} \mathrm{of}$ different plasma proteins and histone IIA.

Notes: Three independent experiments for all proteins were performed. The results were analyzed with two-way analysis of variance and Bonferroni posttests, and significance was determined as follows: $* P<0.05$, $* * P<0.01$, $* * * P<0.001$.

Abbreviations: $\beta 2 \mathrm{GPI}, \beta 2$-glycoprotein I; NT, nanotube; oxlgG A, oxidized IgG A; SAA, serum amyloid $A$.

the binding trend of the proteins. Peptide 1 equally bound to all NTs, regardless of the diameter, with approximately the same low amount. Peptide 2, however, showed high binding to all NTs, with highest binding to $100 \mathrm{~nm}$ NTs. The amount of bound Peptide 2 on $100 \mathrm{~nm}$ NTs exceeded the general amounts of bound proteins on NTs of the same diameter. Moreover, on the NTs with smaller diameters (50 and $15 \mathrm{~nm}$ ) and foil, the amount of bound peptide 2 was still higher than the average amount of any bound proteins on $100 \mathrm{~nm}$ NTs.

\section{Pocket effect and protein denaturation}

In order to determine if the proteins are being adsorbed into the NTs interior (ie, pocket effect), we repeated the washing of the NTs several times (see "Binding of different proteins to $\mathrm{TiO}_{2}$ NTs and protein quantification”). Standard washing was applied the first time and more rigorous washing the second time to flush out the proteins that might still be bound in the interior of the NTs. To examine if the structure of the protein affects the extent of binding on NTs of different diameters, we bound the same quantity of native and denaturated IgGs. Denaturation was achieved using temperature, as well as SDS, $\beta$-mercaptoethanol, and dithiothreitol.

The highest amount of bound native IgG B protein was observed on $100 \mathrm{~nm}$ NTs. Interestingly, the denaturated protein also has the highest amount of binding on $100 \mathrm{~nm}$ NTs and it follows the same pattern as other examined proteins $(100 \mathrm{~nm}$ $\mathrm{NT}>50 \mathrm{~nm} \mathrm{NT}>15 \mathrm{~nm} \mathrm{NT}>$ foil) (Figure 8). Each washing 
A

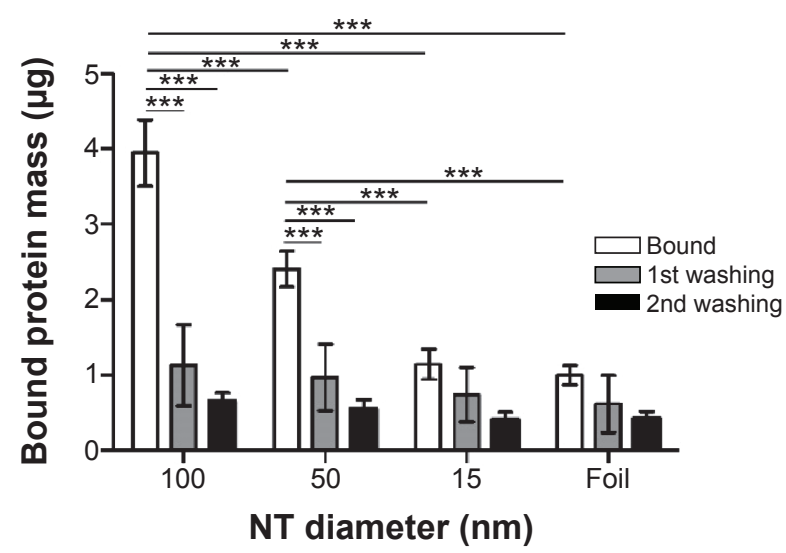

B

Denaturated IgG

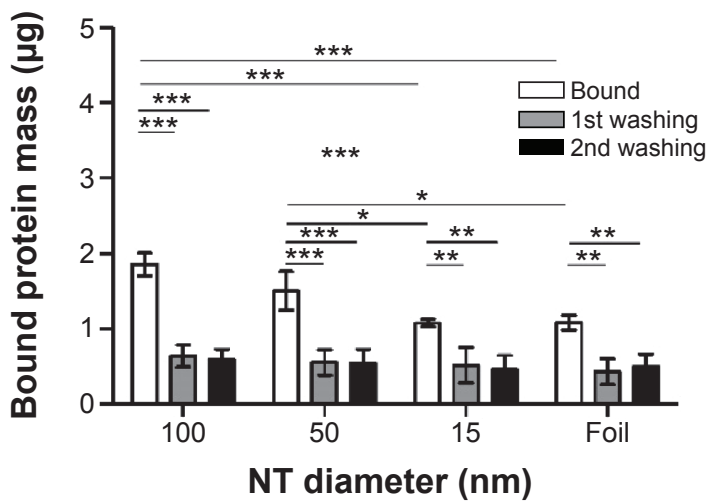

Figure 8 Bound protein mass of native and denaturated IgG B on 100, 50, and $15 \mathrm{~nm} \mathrm{NTs}$ and foil.

Notes: (A) Native lgG B bound protein mass. (B) Denatured lgG B bound protein mass. Two-way analysis of variance and Bonferroni posttests were used to determine significance: $* * * P<0.001, * * P<0.01, * P<0.05$. Five independent experiments for native $\lg \mathrm{B}$ and four for denaturated lgG $\mathrm{B}$ were performed.

Abbreviation: NT, nanotube.

step expectedly reduced the amount of bound proteins, but the pattern remained comparable. Interestingly, the highest amount of washed protein was observed on $100 \mathrm{~nm}$ NTs ( $70 \%$ native and denaturated $\operatorname{IgG}$ B). After the second washing, the mass of bound protein on average decreased by $\sim 15 \%$ as compared to the first washing. A similar decrease of bound proteins was observed on $15 \mathrm{~nm}$ NTs and foil, presumably indicating that IgGs were not bound inside the $15 \mathrm{~nm}$ NTs; however the fact that the second wash was observed at the limit of the BCA technique has to be taken into account.

\section{SAA dose-dependent binding to NTs}

In previous experiments we used relatively high amounts of initial protein concentration due to an optimal range of sensitivity of the BCA method. In order to prevent any results due to supersaturation, we examined the binding of different concentrations of SAA on $100 \mathrm{~nm}$ NTs. Of all non-histone proteins tested, SAA was chosen due to presenting the highest change of bound mass to $100 \mathrm{~nm}$ NTs as compared to foil. We observed that binding of SAA to $100 \mathrm{~nm}$ NTs is dependent on the initial concentrations. The observed bound mass was highest when the highest amount of SAA was applied, and it decreased with lowering the starting concentrations, while no or negligible binding was noted for $30 \mu \mathrm{g}$ of SAA applied to foil (Figure 9). The results were consistent with dose dependency of histone IIA (data not shown). The amount of bound SAA with an initial mass of $30 \mu \mathrm{g}$ was 7.7 -fold higher on $100 \mathrm{~nm}$ NTs than on foil.
A

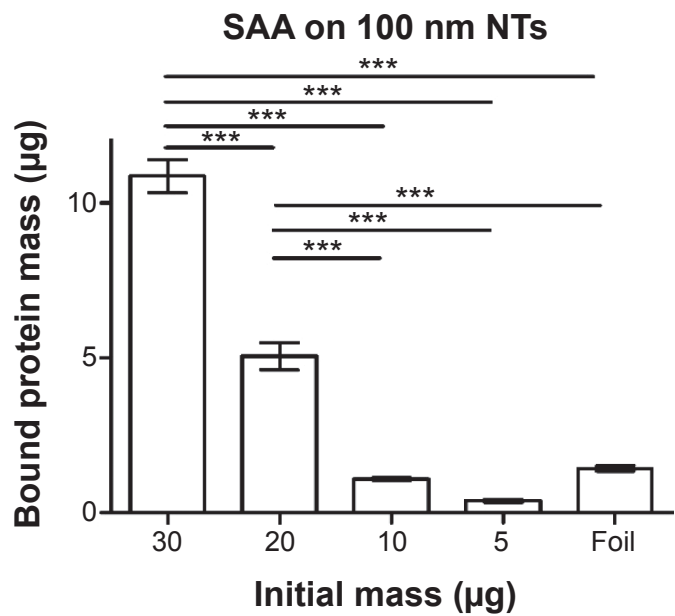

B SAA after $1 \mathrm{st}$ washing
on $100 \mathrm{~nm}$ NTs

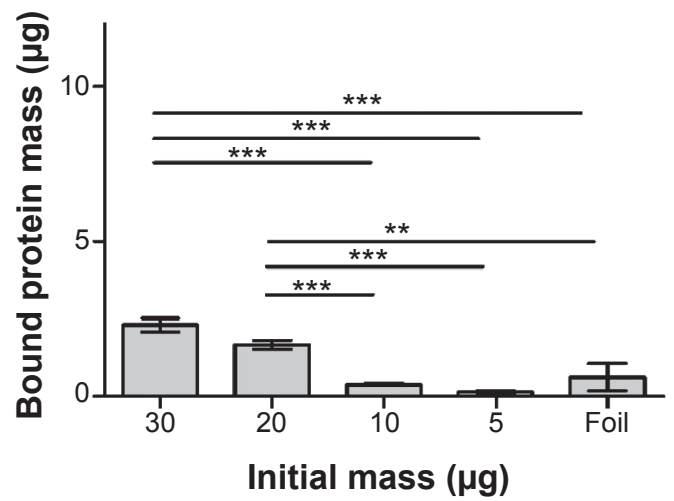

Figure 9 Dose-dependent binding of SAA to $100 \mathrm{~nm}$ NTs and foil using BCA protein assay.

Notes: (A) SAA protein bound to $100 \mathrm{~nm}$ NTs. (B) SAA protein bound following the first washing of the protein indicating the pocket effect. Two-way analysis of variance and Bonferroni posttests were used to determine significance: $* * * P<0.001, * * P<0.01$. The bars represent the average of three independent experiments performed. Abbreviations: NTs, nanotubes; SAA, serum amyloid A. 
A

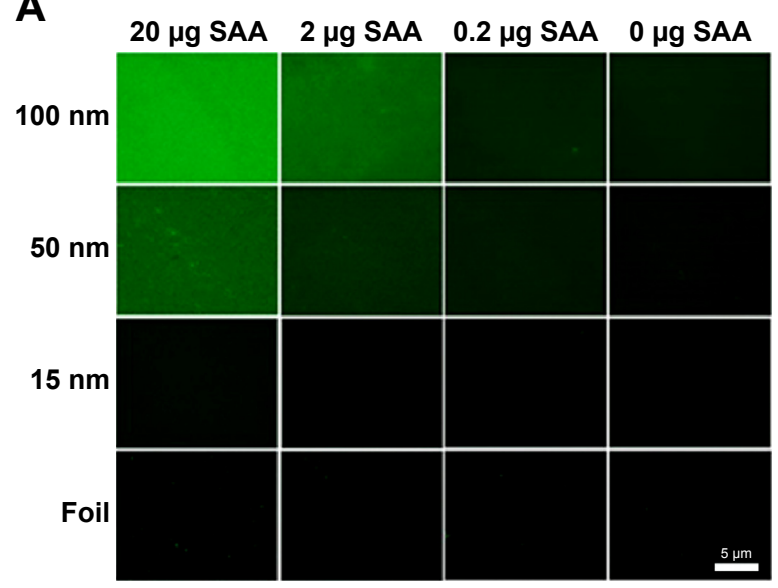

B

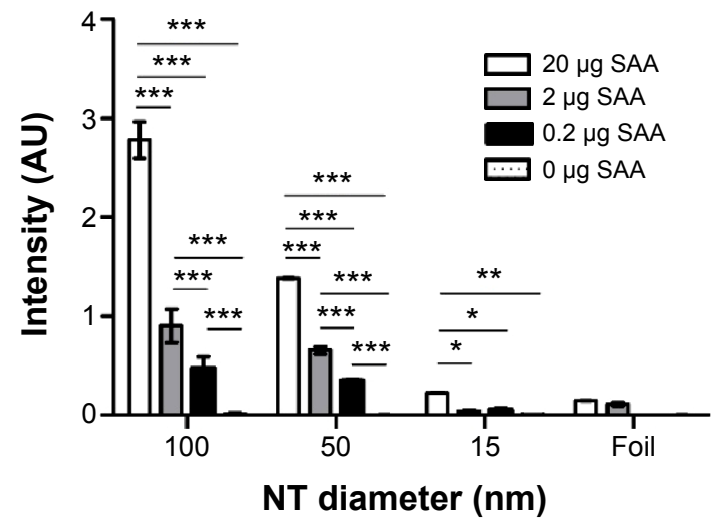

Figure 10 SAA dose dependently binds to NTs with different diameters.

Notes: (A) Immunofluorescence of bound SAA. (B) Average of intensity in arbitrary units was measured and compared with different NT diameters. Two way analysis of variance and Bonferroni posttests were used to determine significance: $* * * P<0.001, * * P<0.01, * P<0.05$. Four independent experiments for each concentration and NT diameter were performed.

Abbreviations: NTs, nanotubes; SAA, serum amyloid A.

\section{Immunofluorescent detection} of dose-dependent SAA binding to NTs with different diameters

To fully confirm dose-dependent binding of SAA on $100 \mathrm{~nm}$ NTs, immunofluorescence was used with different concentrations $(20,2,0.2$, and $0 \mu \mathrm{g})$ of SAA (Figure 10). Immunochemistry was performed by staining, using SAA-specific primary antibodies and fluorophore-conjugated secondary antibodies. We measured the fluorescence intensity on the surface of NTs with different diameters and confirmed the results obtained with $\mathrm{BCA}$ assay. Besides the trend of decreased SAA binding with smaller diameter of NTs, we also confirmed a dose-dependent effect of SAA on the NTs with different diameters (Figure 10).

\section{Theoretical properties of NTs and proteins/peptides}

For the quantification of protein binding on the NTs, one factor often considered is the area of top surface of NTs as well as the total available surface area of the NTs, with consideration of the length of NTs.

The surface areas of the tops of NTs were calculated by using the formula:

$$
A=\pi\left(R^{2}-r^{2}\right)
$$

The values of surface areas of the tops of NTs are given in Table 3. Our calculations showed that $15 \mathrm{~nm}$ NTs have more top surface available than $100 \mathrm{~nm}$ NTs. So, logically, $15 \mathrm{~nm}$ NTs should show more protein binding surface than $100 \mathrm{~nm}$ NTs. However, length of the NTs is another important factor which needs to be taken into consideration when calculating the total surface area available for protein binding (Table 3). To confirm the effect of the length of NTs, we calculated the total surface area of the NTs by summation of the outer surface areas of the NTs (cylindrical), inner surface area of NTs ("V-shape", ie, cone), and the top edges of the NTs. The total surface area is then given by the following formula:

$$
A=2 \pi R h+\pi r \sqrt{r^{2}+h^{2}}+\pi\left(R^{2}-r^{2}\right)
$$

where, $R$ denotes the radius of the outer cylinder, $r$ the radius of the inner cone, and $h$ the height of the nanotube. By counting the number of NTs in the original small area, we calculated the total surface area of NTs in an area of $1 \mathrm{~cm}^{2}$. For the three regimes of different diameters of NTs, the values of total surface areas are given in Table 3.

Theoretical calculation confirms that the $100 \mathrm{~nm}$ diameter NTs have the largest theoretically calculated available surface area for potential protein binding, due to the longer lengths of the NTs.

Spacing between the NTs is a further consideration for protein binding, since smaller-sized proteins can enter

Table 3 Calculated NT surface and edges area, and distances between NTs with different diameters

\begin{tabular}{llll}
\hline & I00 $\mathbf{~ n m}$ & $\mathbf{5 0} \mathbf{~ n m}$ & I5 $\mathbf{~ n m}$ \\
& NTs & NTs & NTs \\
\hline Calculated edges area $\left(\mathrm{cm}^{2}\right)$ & 0.31 & 0.35 & 0.39 \\
Calculated total surface area $\left(\mathrm{cm}^{2}\right)$ & 142.83 & 48.58 & 20.01 \\
Measured distance between the NTs $(\mathrm{nm})$ & 30.8 & 21.4 & 6.3 \\
\hline
\end{tabular}

Abbreviation: NT, nanotube. 
Table 4 Protein IEPs, charge, wettability, and other attributes as determined by IEP calculator, Peptide Property Calculator GenScript2014, and literature

\begin{tabular}{|c|c|c|c|c|c|c|c|}
\hline \multirow{2}{*}{$\begin{array}{l}\text { Proteins and } \\
\text { peptides }\end{array}$} & \multicolumn{2}{|c|}{ IEP } & \multicolumn{2}{|c|}{ Charge and attribute ${ }^{64}$} & \multicolumn{3}{|c|}{ Hydrophilic/hydrophobic properties [\%] ${ }^{64}$} \\
\hline & $\begin{array}{l}\text { IEP } \\
\text { calculators }{ }^{64,65}\end{array}$ & $\begin{array}{l}\text { IEP from } \\
\text { literature }\end{array}$ & $\begin{array}{l}\text { Charge } \\
\text { at pH } 7.4\end{array}$ & Attribute & Hydrophilic & Hydrophobic & Others \\
\hline$\beta 2 \mathrm{GPI}$ & $7.8 / 8.0$ & $5-7^{66}$ & 12 & Basic & 23 & 40 & 37 \\
\hline SAA & $6.1 / 6.3$ & $7.9-9.3^{67}$ & 1 & Basic & 28 & 42 & 31 \\
\hline $\lg G$ & $8.5 / 8.8$ & $6.4-9.0^{68}$ & 7 & Basic & 15 & 38 & 47 \\
\hline Histone IIA & $11.5 / 11.7$ & $11.13^{69}$ & 22 & Basic & 32 & 41 & 26 \\
\hline Peptide I of $\beta 2 \mathrm{GPI}$ & $9.6 / 9.7$ & l & 2 & Basic & 18 & 18 & 64 \\
\hline Peptide 2 of $\beta 2 \mathrm{GPI}$ & $7.4 / 7.6$ & I & I & Basic & 27 & 18 & 55 \\
\hline
\end{tabular}

Note: / indicates that there is no existing data in current literature.

Abbreviations: $\beta 2 \mathrm{GPI}, \beta 2$-glycoprotein I; IEP, isoelectric point; SAA, serum amyloid A.

inside the space between the NTs. For determination of the spacing between NTs, an average value was obtained from statistical measurements performed on SEM images. The average distance/spacing between NTs is taken into account in the modeling. Our calculated theoretical data show that with increasing diameter of the NTs, the spacing between them is also increased, and for the $100 \mathrm{~nm}$ diameter NTs, the observed spacing is approximately five-times greater than the spacing observed for $15 \mathrm{~nm}$ diameter NTs (Table 3).

The plasma proteins used in the current report have different biochemical characteristics important for their binding to NTs' surfaces, such as IEP, charge at $\mathrm{pH} 7.4$, and wettability properties (Table 4 ). The plasma proteins $\beta 2 \mathrm{GPI}$, SAA, and IgG were less basic than histone IIA, where the highest change of binding was also observed experimentally. Although the IEP and charge of the proteins were relatively different, the trend of their binding to NTs of different diameters was similar (Table 2; Figure 7).

\section{Discussion}

It is evident that the response of the surrounding tissue to biomaterials fully depends on its biocompatibility to the material. ${ }^{70}$ Surface properties, surface charge distribution, and submicron structure are some of the key factors in the biological acceptance of the implants.9,71-74 To produce better biocompatible materials, the surfaces of these materials must be nanostructured by increasing their roughness in the nanometer scale. ${ }^{9,75} \mathrm{TiO}_{2}$ NTs meet these criteria on the technical side of nanorough materials. It was our aim to examine which diameter of NTs is more appropriate for protein binding and more suitable (long-term) as nanostructured implant material. Implanted material in contact with blood becomes adhered to plasma proteins ${ }^{13,76}$ once embedded in the body. ${ }^{13}$ Plasma is rich in proteins, carbohydrates, and lipids, as well as lipoprotein and other combinations of complexes; however, when studying clinically relevant proteins, our aim was to first determine their interactions with NTs' surfaces. Lipids can also directly adsorb/bind to the outer surface of $\mathrm{TiO}_{2}$ NTs. This process can be chemisorption with energies stronger than charge interactions. Neutral membrane lipids with zwitterionic headgroups may be electrostatically attracted to negatively charged titanium surfaces as recently shown experimentally and theoretically. ${ }^{77}$ However, in cellular systems, the sugar residues attached to proteins and lipids on the outer cell membrane surface prevent the direct membrane lipid bilayer-titanium interactions, and also abolish short-range attractive van der Waals force and the short range attractive or oscillatory hydration forces between the cell membrane, outer lipid bilayer surfaces, and titanium surface. ${ }^{78}$

As $\mathrm{TiO}_{2}$ surfaces and the cell membranes are both negatively charged, ${ }^{9}$ there is a need for a mediator that shields the repulsive force between the negatively charged biosurfaces. These can be proteins or divalent ions, which can bridge the repulsive electrostatic interactions between equally charged surfaces. Gongadze et al showed that the attraction between the negatively charged $\mathrm{TiO}_{2}$ surface and negatively charged cells is mediated by charged proteins with a distinctive quadrupolar internal charge distribution. ${ }^{9}$

One of the bridging proteins, which directly mediates attractive interactions between charged-charged, chargedneutral, and neutral-neutral phospholipid membranes, is $\beta 2 \mathrm{GPI}^{79,80}$ It was found that $\beta 2 \mathrm{GPI}$ binds to structures with negatively charged phospholipid molecules, thrombocytes, ${ }^{81}$ erythrocytes,${ }^{80}$ and serum lipoproteins $;^{82,83}$ moreover, it binds to phospholipid layers with electrostatic and also hydrophobic interactions. ${ }^{79,80,84} \beta 2 \mathrm{GPI}$ has a positive $\zeta$-potential of $17.80 \mathrm{mV}$. Several domains of $\beta 2 \mathrm{GPI}$ are highly positively charged, ${ }^{85,86}$ which probably contributes to binding to negatively charged $\mathrm{TiO}_{2}$ surfaces. However, we need to consider that other energies, such as chemisorption and hydrophobic interactions, could also be responsible for the interactions. 
The binding of both peptides derived from $\beta 2$ GPI is different from the binding of the total protein $\beta 2 \mathrm{GPI}$. There is a binding difference between peptide 1 and peptide 2, indicating that peptides were not bound with a common $\mathrm{N}$-terminal $\mathrm{GGGS} \mathrm{NH}_{2}$ tail that they share. Peptide 1 showed low binding to all diameters of NTs, where the average mass of bound protein complies with the masses of other proteins bound on $50 \mathrm{~nm}$ NTs. However, peptide 2 highly bound to $100 \mathrm{~nm}$ NTs (in fact, it showed the highest binding of all proteins) and also highly bound on all other diameters. Peptide 2 has a higher percent of hydrophilic residues, as compared to peptide 1 , presumably making greater binding possible.

IgG is the most abundant antibody isotype composed of two heavy and two light polypeptide chains forming a dimer with particular internal charge distribution. ${ }^{79}$ Even though IgG possess a unique quaternary structure, ${ }^{87}$ the binding ratio on NTs remained comparable with other studied proteins. With denaturated IgG, however, the three dimensional conformation was destroyed and, consequentially, the binding was reduced, with the trend of binding with regard to the NTs diameters remaining unchanged. This indicates that the three-dimensional conformation is not the main factor required for binding.

Histone IIA has a $\zeta$-potential of $7.40 \mathrm{mV}$ and is positively charged in physiological conditions, ${ }^{28}$ which is responsible for the tight binding to negatively charged DNA. Gongadze et al proposed that nanorough regions cause an increase of electric field strength and an aggregation of charge which enhances the binding of molecules to the titanium implant surface. ${ }^{9}$

SAA is important in inflammation, infections, and tissue injury during the acute phase response where it can be quickly increased up to 1,000 -fold ${ }^{33}$ and be readily available in the circulation. It is the smallest protein examined in our study with an $\mathrm{Mr} \sim 12 \mathrm{kDa}$, as estimated by SDS-PAGE. It is a globular protein, consisting of 104-112 amino acids, ${ }^{32}$ and containing positively charged proteoglycan-binding domains. ${ }^{88}$

$\mathrm{TiO}_{2}$ NTs present a relatively acidic character for the whole range of considered $\mathrm{pH}$ values. The NTs have an IEP at a $\mathrm{pH}$ of 4.9. The $\zeta$-potential curve reached negative values lower than $-25 \mathrm{mV}$ at $\mathrm{pH}$ values above 6.5. As expected, we observed a decrease in negative $\zeta$-potential values (ie, increase in the absolute value of $\zeta$-potential) with an increase in dilution of PBS solution (ie, with a decrease in salt concentrations) in experiments and theory.

The proteins tested in the present manuscript showed comparable adsorption to NTs (Figure 7). This could be the consequence of many factors, among which are: protein size, charge, conformation, electrostatic interactions, chemisorption, hydrophobic interactions, etc.

It should be stressed that in biological systems, the media in contact with the surface of the titanium implant does not contain only proteins. Inflamed medium is also rich in chelating carboxylates (lactate, citrate) that may change the charge density of the $\mathrm{TiO}_{2}$ surface and also slowly digest $\mathrm{TiO}_{2}$, partially changing its morphology and the surface's chemical and physical (binding) properties.

It is clear that theoretical physical and electrochemical properties of the proteins/peptides, such as surface area, IEPs, molecule size, $\zeta$-potential, charge distribution, and NT wettability, are important and could influence the binding of plasma proteins to $\mathrm{TiO}_{2}$ NTs of different diameters. One of the important issues can be the contact area between the buffer/water on $\mathrm{TiO}_{2} \mathrm{NTs}$, which changes in regard to $\mathrm{TiO}_{2} \mathrm{NT}$ diameter, ${ }^{89}$ as well as wettability of the NTs. More hydrophilic NTs enable a better connection with buffer/water, which is reflected also in the pocket effect and better protein binding on the $100 \mathrm{~nm}$ diameter NTs. However, the current study indicates lower protein binding on smaller-diameter NTs and NTs with shorter lengths, independent of protein size, charge, or conformation, for reasons we have yet to determine.

The pocket effect (defined as the consequence of protein binding to inner nanotube surfaces in depth, both between NTs as well as within each nanotube, following the initial washing steps) could represent an explanation of why proteins bind to a higher degree to $100 \mathrm{~nm}$ NTs.

From the examined literature, it is known that the diameter of the NTs can be a decisive factor for cellular binding, independent of the specific cell type..$^{20,90,91}$ Regardless of the protein's IEP, conformation, charge, or percentage of either hydrophilic or hydrophobic amino residues, the general trend of protein binding remains unchanged (Table 4). The mechanism of protein binding has yet to be elucidated.

Smith et al reported that higher protein binding on NTs was observed due to larger surface area of the NTs, which possess multiple functional sites for the proteins to adsorb. ${ }^{13}$ The protein binding may be changed/optimized by changing the size parameters of $\mathrm{TiO}_{2} \mathrm{NT}$ arrays. ${ }^{13}$ Another research group obtained similar results with binding of collagen type 1 on surfaces of NTs, where faster and higher binding was observed on NTs with larger diameters $(100 \mathrm{~nm})$. The main driving force for collagen type 1 binding was physical adsorption, including van der Waals force and hydrogen bonds between the proline residues of collagen type 1 and NTs. ${ }^{21}$ The authors also calculated the interaction energies, which indicated that $\mathrm{TiO}_{2}$ NTs with larger diameter possess higher 
interaction energies leading to higher protein adsorption. ${ }^{21,92}$ On the other hand, we need to take into account that $100 \mathrm{~nm}$ NTs also possess space between the tubes, which is much smaller than the original diameter. This difference in interspace size decreases with smaller diameters of the NTs. NTs thus possess two different microenvironments for binding, which is an important factor in calculating the total available surface area for binding of proteins, and should be considered due to the possibility that proteins can also go inside the NTs. In the current study, $100 \mathrm{~nm}$ NTs showed comparatively more SAA binding than $15 \mathrm{~nm}$ NTs since the total available surface area of $100 \mathrm{~nm}$ NTs is almost seven-times larger than $15 \mathrm{~nm}$ NTs. Spacing between the NTs is particularly important for the smaller-sized proteins, which can enter inside the space between the NTs more readily. Our theoretically calculated data indicated that with increasing diameter of the NTs, the spacing between the NTs also increases. For example, the spacing between $100 \mathrm{~nm}$ NTs is almost five-times larger than the spacing between $15 \mathrm{~nm}$ NTs. This could prove to be of importance because $\mathrm{TiO}_{2}$ NTs possess great potential for drug-delivery applications. Antibacterial agent release studies showed that with controlling the dimensions of NTs it is possible to prolong the release of antibacterial agent. ${ }^{93}$ NTs loaded with antibiotics have a great potential to become orthopedic implants, with decreased implanted infection rates along with increased osteoblast function. ${ }^{94}$ Different diameters of NTs, as well as their different lengths, can have a consequence on hemocompatibility responses ${ }^{13}$ and on how physiological plasma proteins bind at the blood-nanomaterial interface.

\section{Acknowledgments}

The authors would like to acknowledge Slovenian Research Agency (ARRS) grants J1-4109, J1-4136, J3-4108, P3-0314, and P2-0232 for financial support. The authors also acknowledge the use of equipment in the Center of Excellence on Nanoscience and Nanotechnology - Nanocenter at Jožef Stefan Institute, Ljubljana SI-1000, Slovenia and Mitja Drab for his help in calculating the surface areas of nanotubes. The contribution of A. Artenjak preceded his employment at the current institution/company.

\section{Disclosure}

The authors report no conflicts of interest in this work.

\section{References}

1. Wang RR, Fenton A. Titanium for prosthodontic applications: a review of the literature. Quintessence Int. 1996;27(6):401-408.

2. Jokstad A, Braegger U, Brunski JB, Carr AB, Naert I, Wennerberg A. Quality of dental implants. Int J Prosthodont. 2004;17(6):607-641.
3. Heo SJ, Sennerby L, Odersjö M, Granström G, Tjellström A, Meredith N. Stability measurements of craniofacial implants by means of resonance frequency analysis. A clinical pilot study. J Laryngol Otol. 1998;112(6):537-542.

4. Eufinger $\mathrm{H}$, Wehmöller M. Individual prefabricated titanium implants in reconstructive craniofacial surgery: clinical and technical aspects of the first 22 cases. Plast Reconstr Surg. 1998;102(2):300-308.

5. Peng L, Eltgroth ML, LaTempa TJ, Grimes CA, Desai TA. The effect of $\mathrm{TiO} 2$ nanotubes on endothelial function and smooth muscle proliferation. Biomaterials. 2009;30(7):1268-1272.

6. Fine E, Zhang LJ, Fenniri H, Webster TJ. Enhanced endothelial cell functions on rosette nanotube-coated titanium vascular stents. Int $J$ Nanomedicine. 2009;4:91-97.

7. Mihov D, Katerska B. Some biocompatible materials used in medical practice. Trakia Journal of Sciences. 2009;8(2):119-125.

8. Williams DF. On the mechanisms of biocompatibility. Biomaterials. 2008;29(20):2941-2953.

9. Gongadze E, Kabaso D, Bauer S, et al. Adhesion of osteoblasts to a nanorough titanium implant surface. Int J Nanomedicine. 2011;6:1801-1816.

10. Lee K, Mazare A, Schmuki P. One-dimensional titanium dioxide nanomaterials: nanotubes. Chem Rev. 2014;114(19):9385-9454.

11. Diebold U. The surface science of titanium dioxide. Surf Sci Rep. 2003; 48(5-8):53-229.

12. Puckett SD, Taylor E, Raimondo T, Webster TJ. The relationship between the nanostructure of titanium surfaces and bacterial attachment. Biomaterials. 2010;31(4):706-713.

13. Smith BS, Yoriya S, Grissom L, Grimes CA, Popat KC. Hemocompatibility of titania nanotube arrays. J Biomed Mater Res A. 2010;95(2): 350-360.

14. Kulkarni M, Mazare A, Gongadze E, et al. Titanium nanostructures for biomedical applications. Nanotechnology. 2015;26:062002.

15. Casarin M, Maccato C, Vittadini A. Molecular chemisorption on $\mathrm{TiO}_{2}(110)$ : A local point of view. J Phys Chem B. 1998;102(52):10745-10752.

16. Linsebigler A, Lu G, Yates JT Jr. CO chemisorption on $\mathrm{Tio}_{2}(110)$ oxygen vacancy site influence on CO adsorption. J Chem Phys. 1995; 103(21):9438-9443.

17. Sano KI, Shiba K. A hexapeptide motif that electrostatically binds to the surface of titanium. $J$ Am Chem Soc. 2003;125(47):14234-14235.

18. Bauer S, Park J, Pittrof A, Song YY, von der Mark K, Schmuki P. Covalent functionalization of $\mathrm{TiO} 2$ nanotube arrays with EGF and BMP-2 for modified behavior towards mesenchymal stem cells. Integr Biol (Camb). 2011;3(9):927-936.

19. Deng ZJ, Mortimer G, Schiller T, Musumeci A, Martin D, Minchin RF. Differential plasma protein binding to metal oxide nanoparticles. Nanotechnology. 2009;20(45):455101.

20. Park J, Bauer S, Schlegel KA, Neukam FW, von der Mark K, Schmuki P. TiO2 nanotube surfaces: $15 \mathrm{~nm}$ - an optimal length scale of surface topography for cell adhesion and differentiation. Small. 2009;5(6): 666-671.

21. Yang W, Xi X, Ran Q, Liu P, Hu Y, Cai K. Influence of the titania nanotubes dimensions on adsorption of collagen: an experimental and computational study. Mater Sci Eng C Mater Biol Appl. 2014;34:410-416.

22. Balasundaram G, Yao C, Webster TJ. TiO2 nanotubes functionalized with regions of bone morphogenetic protein-2 increases osteoblast adhesion. J Biomed Mater Res A. 2008;84(2):447-453.

23. Cao X, Yu WQ, Qiu J, Zhao YF, Zhang YL, Zhang FQ. RGD peptide immobilized on $\mathrm{TiO} 2$ nanotubes for increased bone marrow stromal cells adhesion and osteogenic gene expression.J Mater Sci Mater Med. 2012;23(2):527-536.

24. Werner S, Huck O, Frisch B, et al. The effect of microstructured surfaces and laminin-derived peptide coatings on soft tissue interactions with titanium dental implants. Biomaterials. 2009;30(12):2291-2301.

25. Reinhardt M, Giri S, Bader A. Preclinical Challenges and Clinical Target of Nanomaterials in Regenerative Medicine. In: Suar M, Salhotra A, Soni S, editors. Handbook of Research on Diverse Applications of Nanotechnology in Biomedicine, Chemistry, and Engineering. Hershey: IGI Global; 2014:350-371. 
26. Kulkarni M, Mazare A, Schmuki P, Iglic A. Biomaterial surface modification of titanium and titanium alloys for medical applications. In: Seifalian A, editor. Nanomedicine. UK Central Press; 2014:11-136.

27. Smith BS, Popat KC. Titania nanotube arrays as interfaces for bloodcontacting implantable devices: a study evaluating the nanotopographyassociated activation and expression of blood plasma components. J Biomed Nanotechnol. 2012;8(4):642-658.

28. Katsani KR, Arredondo JJ, Kal AJ, Verrijzer CP. A homeotic mutation in the trithorax SET domain impedes histone binding. Genes Dev. 2001;15(17):2197-2202.

29. Elgin SC, Weintraub H. Chromosomal proteins and chromatin structure. Annu Rev Biochem. 1975;44:724-774.

30. Gabay C, Kushner I. Acute-phase proteins and other systemic responses to inflammation. N Engl J Med. 1999;340(6):448-454.

31. Lakota K, Thallinger GG, Cucnik S, et al. Could antibodies against serum amyloid A function as physiological regulators in humans? Autoimmunity. 2011;44(2):149-158.

32. Uhlar CM, Whitehead AS. Serum amyloid A, the major vertebrate acute-phase reactant. Eur J Biochem. 1999;265(2):501-523.

33. Upragarin N, Landman WJ, Gaastra W, Gruys E. Extrahepatic production of acute phase serum amyloid A. Histol Histopathol. 2005;20(4): 1295-1307.

34. Stevens FJ. Hypothetical structure of human serum amyloid A protein. Amyloid. 2004;11(2):71-80.

35. Chiu WC, Chiou TJ, Chiang AN. $\beta_{2}$-Glycoprotein I inhibits endothelial cell migration through the nuclear factor $\kappa \mathrm{B}$ signalling pathway and endothelial nitric oxide synthase activation. Biochem J. 2012; 445(1):125-133.

36. Lozier J, Takahashi N, Putnam FW. Complete amino acid sequence of human plasma beta 2-glycoprotein I. Proc Natl Acad Sci U S A. 1984; 81(12):3640-3644.

37. Lin F, Murphy R, White B, et al. Circulating levels of beta2-glycoprotein I in thrombotic disorders and in inflammation. Lupus. 2006; 15(2):87-93.

38. Lozier J, Takahashi N, Putnam FW. Complete amino acid sequence of human plasma beta 2-glycoprotein I. Proc Natl Acad Sci U S A. 1984; 81(12):3640-3644.

39. Schwarzenbacher R, Zeth K, Diederichs K, et al. Crystal structure of human beta2-glycoprotein I: implications for phospholipid binding and the antiphospholipid syndrome. EMBO J. 1999;18(22):6228-6239.

40. Hunt JE, Simpson RJ, Krilis SA. Identification of a region of beta 2-glycoprotein I critical for lipid binding and anti-cardiolipin antibody cofactor activity. Proc Natl Acad Sci US A. 1993;90(6):2141-2145.

41. de Laat B, Derksen RH, van Lummel M, Pennings MT, de Groot PG. Pathogenic anti-beta2-glycoprotein I antibodies recognize domain I of beta2-glycoprotein I only after a conformational change. Blood. 2006; 107(5):1916-1924.

42. Zager U, Kveder T, Cučnik S, Božič B, Lunder M. Anti- $\beta 2$-glycoprotein I paratopes and $\beta 2$-glycoprotein I epitopes characterization using random peptide libraries. Autoimmunity. 2014;47(7):438-444.

43. Miyakis S, Lockshin MD, Atsumi T, et al. International consensus statement on an update of the classification criteria for definite antiphospholipid syndrome (APS). J Thromb Haemost. 2006;4(2):295-306.

44. Jefferis R. Autoantibodies. In: Male D, Brostoff J, Roth DB, Roitt IM, editors. Immunology. 8th ed. Elsevier; 2013:51-70.

45. Dimitrov JD, Planchais C, Kang J, et al. Heterogeneous antigen recognition behavior of induced polyspecific antibodies. Biochem Biophys Res Commun. 2010;398(2):266-271.

46. McIntyre JA, Faulk WP. Redox-reactive autoantibodies: biochemistry, characterization, and specificities. Clin Rev Allergy Immunol. 2009; 37(1):49-54.

47. Omersel J, Jurgec I, Cucnik S, et al. Autoimmune and proinflammatory activity of oxidized immunoglobulins. Autoimmun Rev. 2008;7(7):523-529.

48. Omersel J, Avberšek-Lužnik I, Grabnar PA, Kveder T, Rozman B, Božič B. Autoimmune reactivity of $\operatorname{IgM}$ acquired after oxidation. Redox Rep. 2011;16(6):248-256.
49. Sun S, Yu W, Zhang Y, Zhang F. Increased preosteoblast adhesion and osteogenic gene expression on $\mathrm{TiO} 2$ nanotubes modified with KRSR. J Mater Sci Mater Med. 2013;24(4):1079-1091.

50. Ma MH, Kazemzadeh-Narbat M, Hui Y, et al. Local delivery of antimicrobial peptides using self-organized $\mathrm{TiO} 2$ nanotube arrays for periimplant infections. J Biomed Mater Res A. 2012;100(2):278-285.

51. Assefpour-Dezfuly M, Vlachos C, Andrews EH. Oxide morphology and adhesive bonding on titanium surfaces. J Mater Sci. 1984;19(11): 3626-3639.

52. Kowalski D, Kim D, Schmuki P. TiO nanotubes, nanochannels and mesosponge: Self-organized formation and applications. Nano Today. 2013;8(3):235-264.

53. Macak JM, Tsuchiya H, Ghicov A, et al. TiO nanotubes: Self-organized electrochemical formation, properties and applications. Curr Opin Solid State Mater Sci. 2007;11(1-2):3-18.

54. Macak JM, Taveira LV, Tsuchiya H, Sirotna K, Macak J, Schmuki P. Influence of different fluoride containing electrolytes on the formation of self-organized titania nanotubes by Ti anodization. Journal of Electroceramics. 2006;16(1):29-34.

55. Zhou XM, Nguyen NT, Ozkan S, Schmuki P. Anodic TiO2 nanotube layers: Why does self-organized growth occur-A mini review. Electrochem Commun. 2014;46:157-162.

56. Smith BS, Yoriya S, Johnson T, Popat KC. Dermal fibroblast and epidermal keratinocyte functionality on titania nanotube arrays. Acta Biomater. 2011;7(6):2686-2696.

57. Kim D, Fujimoto S, Schmuki P, Tsuchiya H. Nitrogen doped anodic $\mathrm{TiO}_{2}$ nanotubes grown from nitrogen-containing Ti alloys. Electrochem Commun. 2008;10(6):910-913.

58. Paulose M, Prakasam HE, Varghese OK, et al. $\mathrm{TiO}_{2}$ nanotube arrays of $1000 \mu \mathrm{m}$ length by anodization of titanium foil: Phenol red diffusion. J Phys Chem C. 2007;111(41):14992-14997.

59. Gongadze E, Iglič A. Decrease of permittivity of an electrolyte solution near a charged surface due to saturation and excluded volume effects. Bioelectrochemistry. 2012;87:199-203.

60. Velikonja A, Gongadze E, Kralj-Iglič V, Iglič A. Charge dependent capacitance of Stern layer and capacitance of electrode/electrolyte interface. International Journal of Electrochemical Science. 2014;9: 5885-5894.

61. Artenjak A, Leonardi A, Križaj I, et al. Optimization of unnicked $\beta 2$-glycoprotein I and high avidity anti- $\beta 2$-glycoprotein I antibodies isolation. J Immunol Res. 2014;2014:195687.

62. Artenjak A, Kozelj M, Lakota K, Cucnik S, Bozic B, Sodin-Semrl S. High avidity andi-beta 2-glycoprotein I antibodies activate human coronary artery endothelial cells and trigger peripheral blood mononuclear cell migration. Eur J Inflamm. 2013;11(2):385-396.

63. Gongadze E, Velikonja A, Perutkova $\breve{S}$, et al. Ions and water molecules in an electrolyte solution in contact with charged and dipolar surfaces. Electrochim Acta. 2014;126:42-60.

64. Peptide Property Calculator [webpage on the Internet]. Piscataway: Genscript, Inc.; 2014 [cited September 10, 2014]. Avaiable from: https:// www.genscript.com/ssl-bin/site2/peptide_calculation.cgi. Accessed November 12, 2014.

65. Calculation of protein isoelectric point [webpage on the Internet]. Poland: Kozlowski LP; 2013 [cited October 2, 2014]. Available from: http://isoelectric.ovh.org/. Accessed October 2, 2014.

66. Buttari B, Profumo E, Mattei V, et al. Oxidized beta2-glycoprotein I induces human dendritic cell maturation and promotes a T helper type 1 response. Blood. 2005;106(12):3880-3887.

67. Jacobsen S, Niewold TA, Halling-Thomsen M, et al. Serum amyloid A isoforms in serum and synovial fluid in horses with lipopolysaccharide-induced arthritis. Vet Immunol Immunopathol. 2006; 110(3-4):325-330.

68. Griffin:Antibody Basics [webpage on the Internet]. OpenWetWare: 2014 [updated March 18, 2014; cited September 3, 2014]. Available from: http://openwetware.org/wiki/Griffin:Antibody_Basics. Accessed November 6, 2014 
69. Protein Page: H3 (human) [webpage on the Internet]. Cell Signaling Technology, Inc.; 2013 [cited September 4, 2014]. Available from: http:// www.phosphosite.org/proteinAction.do?id=7541\&showAllSites=true. Accessed November 12, 2014.

70. Nuss KM, von Rechenberg B. Biocompatibility issues with modern implants in bone - a review for clinical orthopedics. Open Orthop J. 2008; 2:66-78.

71. Kasemo B. Biological surface science. Surf Sci. 2002;500(1-3): 656-677.

72. Nebe JG, Luethen F, Lange R, Beck U. Interface interactions of osteoblasts with structured titanium and the correlation between physicochemical characteristics and cell biological parameters. Macromol Biosci. 2007;7(5):567-578.

73. Anselme K, Bigerelle M, Noel B, et al. Qualitative and quantitative study of human osteoblast adhesion on materials with various surface roughnesses. J Biomed Mater Res. 2000;49(2):155-166.

74. Mrksich M, Whitesides GM. Using self-assembled monolayers to understand the interactions of man-made surfaces with proteins and cells. Annu Rev Biophys Biomol Struct. 1996;25:55-78.

75. Vasilev K, Poh Z, Kant K, Chan J, Michelmore A, Losic D. Tailoring the surface functionalities of titania nanotube arrays. Biomaterials. 2010; 31(3):532-540.

76. Tang L, Eaton JW. Natural responses to unnatural materials: A molecular mechanism for foreign body reactions. Mol Med. 1999;5(6):351-358

77. Velikonja A, Santhosh PB, Gongadze E, et al. Interaction between dipolar lipid headgroups and charged nanoparticles mediated by water dipoles and ions. Int J Mol Sci. 2013;14(8):15312-15329.

78. Israelachvili J, Wennerström $\mathrm{H}$. Role of hydration and water structure in biological and colloidal interactions. Nature. 1996;379(6562):219-225.

79. Urbanija J, Tomsic N, Lokar M, et al. Coalescence of phospholipid membranes as a possible origin of anticoagulant effect of serum proteins. Chem Phys Lipids. 2007;150(1):49-57.

80. Lokar M, Urbanija J, Frank M, et al. Agglutination of like-charged red blood cells induced by binding of beta2-glycoprotein I to outer cell surface. Bioelectrochemistry. 2008;73(2):110-116.

81. Schousboe I. Binding of beta-2-glycoprotein I to platelets: effect of adenylate cyclase activity. Thromb Res. 1980;19(1-2):225-237.

82. Polz E, Kostner GM. Binding of beta 2-glycoprotein I to human serum lipoproteins: distribution among density fractions. FEBS Lett. 1979; 102(1):183-186
83. Kobayashi K, Kishi M, Atsumi T, et al. Circulating oxidized LDL forms complexes with beta2-glycoprotein I: implication as an atherogenic autoantigen. J Lipid Res. 2003;44(4):716-726.

84. Wang SX, Cai GP, Sui SF. The insertion of human apolipoprotein $\mathrm{H}$ into phospholipid membranes: a monolayer study. Biochem J. 1998; 335(Pt 2):225-232.

85. Kertesz Z, Yu BB, Steinkasserer A, Haupt H, Benham A, Sim RB. Characterization of binding of human beta 2-glycoprotein I to cardiolipin. Biochem J. 1995;310(Pt 1):315-321.

86. Bouma B, de Groot PG, van den Elsen JM, et al. Adhesion mechanism of human beta(2)-glycoprotein I to phospholipids based on its crystal structure. EMBO J. 1999;18(19):5166-5174.

87. Kilár F, Simon I, Lakatos S, Vonderviszt F, Medgyesi GA, Závodszky P. Conformation of human IgG subclasses in solution. Small-angle X-ray scattering and hydrodynamic studies. Eur J Biochem. 1985;147(1): $17-25$.

88. Chiba T, Chang MY, Wang S, et al. Serum amyloid A facilitates the binding of high-density lipoprotein from mice injected with lipopolysaccharide to vascular proteoglycans. Arterioscler Thromb Vasc Biol. 2011;31(6):1326-1332.

89. Kulkarni M, Patil-Sen Y, Junkar I, Kulkarni CV, Iglic A. Wettability Studies of Topologically Distinct Titanium Surfaces. In press 2014.

90. Park J, Bauer S, Schmuki P, Schlegel K, Neukam F, von der Mark K. Nanotube diameter directs stem cell fate. J Stem Cells Regen Med. 2007;2(1):168

91. Park J, Bauer S, Schmuki P, von der Mark K. Narrow window in nanoscale dependent activation of endothelial cell growth and differentiation on TiO2 nanotube surfaces. Nano Lett. 2009;9(9):3157-3164.

92. Yang XM, Li M, Lin X, et al. Enhanced in vitro biocompatibility/ bioactivity of biodegradable $\mathrm{Mg}-\mathrm{Zn}-\mathrm{Zr}$ alloy by micro-arc oxidation coating contained Mg2SiO4. Surf Coat Tech. 2013;233:65-73.

93. Caliskan N, Bayram C, Erdal E, Karahaliloğlu Z, Denkbaş EB. Titania nanotubes with adjustable dimensions for drug reservoir sites and enhanced cell adhesion. Mater Sci Eng C Mater Biol Appl. 2014;35 $100-105$.

94. Zhang HZ, Sun Y, Tian A, et al. Improved antibacterial activity and biocompatibility on vancomycin-loaded $\mathrm{TiO} 2$ nanotubes: in vivo and in vitro studies. Int J Nanomedicine. 2013;8:4379-4389.
International Journal of Nanomedicine

\section{Publish your work in this journal}

The International Journal of Nanomedicine is an international, peerreviewed journal focusing on the application of nanotechnology in diagnostics, therapeutics, and drug delivery systems throughout the biomedical field. This journal is indexed on PubMed Central,

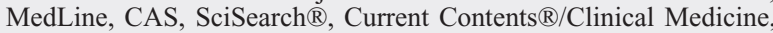

\section{Dovepress}

Journal Citation Reports/Science Edition, EMBase, Scopus and the Elsevier Bibliographic databases. The manuscript management system is completely online and includes a very quick and fair peer-review system, which is all easy to use. Visit http://www.dovepress.com/ testimonials.php to read real quotes from published authors. 